\title{
Ibbm Pelatihan Pelestarian Situs Sejarah Berbasis Kearifan Lokal Di Desa Nagaratengah Kecamatan Cineam Kabupaten Tasikmalaya
}

\author{
Iyus Jayusman, Oka Agus Kurniawan Shavab, Zulpi Miftahudin \\ Universitas Siliwangi \\ Email: okaaks@unsil.ac.id,081809075795
}

\begin{abstract}
ABSTRAK
Berdasarkan observasi yang dilakukan bahwa masyarakat di kecamatan Cineam khususnya di Desa Nagaratengah belum memiliki pemahaman tentang bagaimana mengatasi masalah jika terjadi kerusakan pada benda-benda Cagar Budaya/situs sejarah di wilayahnya. Padahal pengetahuan ini sangat penting dan diperlukannya peran serta masyarakat untuk menjaganya. Tujuan dari diadakannya pengabdian masyarakat ini adalah meningkatkan kemampuan masyarakat dalam melestarikan situs sejarah berbasis kearifan lokal di Desa Nagaratengah Kecamatan Cineam Kabupaten Tasikmalaya. Metode yang digunakan dalam melakukan pengabdian ini adalah dengan melakukan kegiatan pelatihan. Konsep pelatihan pelestarian situs yang diberikan berdasarkan pada kearifan lokal yang dimiliki oleh Masyarakat Nagaratengah Kecamatan Cineam yaitu berdasarkan pada kepercayaan, tradisi, adat, organisasiorganisasi sosial, dan sistem pengelolaan. Pelatihan yang diberikan berupa penyuluhan kepada masyarakat bagaimana cara melalakukan pelestarian situs dan pengelolaan lingkungan di area situs dengan selalu menjaga kebersihan situs. Beberapa hal yang dapat membangun sinergi dan keterlibatan masyarakat dalam pelestarian situs, antara lain : (1). Merumuskan komitmen bersama dan menyatukan visi, misi dalam pelestarian situs yang berbasis pada kearifan lokal berupa organisasi-organisasi sosial yang terdapat pada masyarakat Nagaratengah; (2). Membentuk kemandirian dalam upaya menjalin keharmonisan antar masyarakat; (3) Bergerak dalam keragaman untuk melalui proses yang penuh tantangan; (4).Mengaktifkan organisasiorganisasi yang ada di masyarakat dan media sosial dalam konsep pelestarian situs.
\end{abstract}

Kata Kunci: Pelestarian Situs Sejarah, Kearifan Lokal, Sejarah Lokal

\begin{abstract}
Based on observations made by people in Cineam sub-district specifically in Nagaratengah Village, they do not yet have an understanding of how to deal with problems that occur on Cultural Heritage objects / historical sites in their area. While this knowledge is very important and community participation is required to protect it. The purpose of holding this community service is to improve the community's ability to preserve historical wisdom-based historical sites in Nagaratengah Village, Cineam District, Tasikmalaya Regency. The method used in conducting this service is to conduct training activities. The concept of site preservation training provided on local wisdom provided by the Nagaratengah Community of Cineam District is based on beliefs, traditions, customs, social organizations, and management systems. The training was given about counseling to the community on how to do site conservation and environmental management at the site by always maintaining site cleanliness. Some things that can build synergies and involve the community in conservation sites include: (1). Formulate joint commitment and unite vision, mission in the preservation of sites based on local wisdom consisting of social organizations included in Nagaratengah society; (2) Establishing independence in an effort to establish harmony between communities; (3) Moves in Differences to a competitive process; (4). Activating organizations in the community and social media in the concept of site conservation.
\end{abstract}

Keywords: Historical Preservation Sites, Local Wisdom, Local History 


\section{PENDAHULUAN}

Pelestarian situs sejarah oleh masyarakat terhadap situs sejarah saat ini masih kurang sehingga pelestarian situs sejarah hanya dipahami sebagai masa lampau yang kurang memiliki makna dan hanya dianggap sebagai peristiwa yang tidak perlu dipelajari dan dijaga keberadaannya, pada hakikatnya ilmu sejarah senantiasa berusaha menggali serta mengungkap fakta yang sebenarnya agar menjadi realistis, tidak hanya sebatas imajinasi atau cerita saja tetapi berdasarkan konsep-konsep yang nyata. Seiring dengan perkembangan masyarakat yang semakin maju dan modern, dimana masyarakat memahami sejarah bukan sebagai peristiwa tetapi sebagai kisah akhirnya hilang tanpa ada sumber untuk diwariskan pada gennerasi berikutnya dan peninggalan atau situs-situs sejarah keberadaannya kurang terawat bahkan hilang.

Pelestarian merupakan salah satu upaya dalam pelestarian suatu cagar budaya ataupun tinggalan arkeologis yang belum ditetapkan sebagai cagar budaya. Salah satunya adalah konservasi tinggalan arkeologis dengan memanfaatkan kearifan lokal masyarakat yang berada di sekitar situs. Pelestarian dilakukan agar tinggalan arkeologis tersebut dapat dilestarikan dan terhindar dari kerusakan, atau meminimalisir kerusakan tinggalan tersebut. Upaya pelestarian dapat dikatakan sebagai salah satu tindakan pelindungan. Berdasarkan uraian tersebut, pelestarian merupakan upaya pelindungan terhadap objek material dari masa lalu yang dilakukan agar benda-benda tersebut dapat dilestarikan. Secara umum pada acara Workshop pelestarian Cagar Budaya Berbasis Kearifan Tradisional pelestarian situs sejarah dilakukan terhadap tinggalan arkeologis berbahan kayu, logam, batu, tanah liat, keramik, bata, bambu, manik-manik, lontar, dan lain sebaginya.

Upaya pelestarian terhadap tinggalan arkeologis berbentuk situs sejarah yang merupakan satu kesatuan utuh dengan bentang lahannya (landscape), serta memiliki cakupan luas. Salah satu bentuk tinggalan arkeologis berbentuk situs adalah situs Nagaratengah.

Status situs tersebut, saat ini masih dalam proses pelestarian untuk kemudian diajukan sebagai cagar budaya oleh Pemerintah Kabupaten Tasikmalaya. Berkenaan dengan pelestarian situs berbasis kearifan lokal di situs tersebut, tampak adanya indikasi kerusakan apabila hal ini terus terjadi tidak menutup kemungkinan keberdaan situs tersebut akan hilang. Selain itu, pelestarian yang akan dilakukan untuk menjaga kerusakan dari yang disebabkan oleh alam karena lokasi situs tersebut berada di pinggiran sungai, sehingga kerusakan akibat erosi dan pengikisan oleh air akan semakin cepat, sehingga perlu dilakukan upaya pelestarian secepatnya dalam menjaga keberadaan situs nagaratengah.

Adapun konsep konservasi berbasis kearifan lokal secara umum dapat dimaknai sebagai suatu sistem yang mengintegrasikan antara pengetahuan, kelembagaan, serta praktik pengelolaan sumber daya yang ada pada masyarakat dalam menyusun dan menata materi 
sebagai suatu respon terhadap kondisi lingkungan dan daya antisipatif terhadap perubahan kondisi lingkungan. Lingkungan budaya, ataupun lingkungan sosialnya.

Pelestarian untuk membangun kembali kepedulian masyarakat terhadap situs sejarah sebagai bukti perjalanan bangsa dan pengembangan ke Ilmuan Sejarah, disamping itu, untuk membangun dan kepekaan sosial masyarakat dalam partisipasinya menjaga dan melestarikan situs-situs sejarah untuk selalu memperhatikan dan secara konsisten mensosialisasikan keberadaan situs sejarah dalam rangka melestarikan dan memperkenalkan kepada masyarakat agar keberadaanya tidak dilupakan, selalu dijaga, dan dirawat untuk kepentingan generasi muda dimasa yang akan datang agar tidak kehilangan jejak dan arah hidup serta mampu menghargai peninggalan-peninggalan bersejarah, sehingga muncul karakter yang peduli dan tertanam nilainilai nasionalisme.

\section{BAHAN DAN METODE}

Kegiatan pengabdian pada masyarakat ini dilaksanakan tanggal 26 Agustus 2018 di desa Nagaratengah Kecamatan Cineam Kabupaten Tasikmalaya. Populasi pada pengabdian masyarakat ini adalah seluruh masyarakat desa Nagaratengah dan sampelnya sebanyak 25 orang yang terdiri dari perwakilan. Teknik sampling yang digunakan adalah purpossive sampling, yaitu menentukan pengambilan sampel dengan cara menetapkan ciri-ciri khusus yang sesuai dengan tujuan pengabdian sehingga diharapkan dapat menjawab permasalahan pengabdian masyarakat. Untuk teknik pengumpulan data digunakan dengan menggunakan catatan lapangan dan lembar observasi. Analisis data yang digunakan dalam kegiatan pengabdian ini adalah dengan menggunakan analisis Triangulasi. Metode yang digunakan dalam kegiatan pengabdian ini dilakukan dengan cara memberikan ceramah, diskusi, dan pelatihan.

\section{HASIL DAN PEMBAHASAN}

Keberadaan benda Cagar Budaya di Situs sejarah Cineam Kabupaten Tasikmalaya masih rawan dari kerusakan dan kemusnahan, baik yang disebabkan oleh faktor alam maupun ulah manusia. Untuk itu perlu diungkap bagaimana perlindungan hukumnya dan apakah peraturan perundang - undangan yang ada sudah memadai dalam upaya memberikan perlindungan terhadap benda-benda tersebut. Kurangnya apresiasi terhadap benda cagar budaya/situs sejarah menjadi salah satu faktor semakin tingginya ancaman, seperti perusakan, dan pemalsuan terhadap situs sejarah yang ada di Kecamatan Cineam Kabupaten Tasikmalaya. Kondisi tersebut diperparah lagi dengan kurangnya sosialisasi tentang hukum perlindungan terhadap benda cagar budaya/situs sejarah itu sendiri serta keadaan ekonomi masyarakat yang masih minim.

Situs sejarah di kecamatan Cineam adalah salah satu Cagar Budaya Kabupaten Tasikmalaya yang harus dan mendesak dalam pembuatan Perda tentang Cagar Budaya tersebut 
agar benda-benda Cagar Budaya/situs sejarah terlindungi. Karena Perda Kabupaten Tasikmalaya tentang Cagar Budaya belum ada maka Undang-Undang Republik Indonesia Nomor 11 Tahun 2010 tentang Cagar Budaya sangatlah berperan penting untuk melindungi dan mel estarikan Situs sejarah di kecamatan Cineam.

Selain alasan normatif, urgensi sosisologis juga sangat dibutuhkan mengingat masyarakat juga berperan penting dalam pelestarian Situs sejarah di Cineam. Peran serta tokoh masyarakat dalam upaya pelestarian situs sejarah adalah hal yang harus dilakukan, karena situs sejarah merupakan rekaman jejak masa lalu yang harus dirawat dan dilestarikan karena memberikan pesan kejadian pada masa tersebut, sehingga masyarakat saat ini dapat mengambil nilai-nilai yang terkandung di dalamnya. Oleh sebab itu, situs sejarah harus dilestarikan dan dipertahankan, sehingga membutuhkan peran masyarakat dalam melakukan pelestariannya. Situs sejarah di Cineam karena lingkungan sekitar juga sangat mempengaruhi dalam pelestarian Situs sejarah tersebut.

Pelestarian kawasan cagar budaya/situs sejarah adalah segenap proses konservasi, interpretasi, dan manajemen terhadap suatu kawasan agar makna kultural yang terkandung dapat terpelihara dengan baik. Dalam sebuah pelestarian kawasan cagar budaya/situs sejarah perlu disediakan kesempatan kepada masyarakat yang bertanggung jawab kultural terhadap kawasan tersebut untuk ikut berpartisipasi dalam proses pelestarian. Kriteria pelestarian dapat diukur dari kekhasan kawasan, kesejarahan kawasan, keistimewaan kawasan, dan partisipasi masyarakat.

Masyarakat di kecamatan Cineam belum memiliki pemahaman tentang bagaimana pertanggung jawaban jika terjadi kerusakan benda-benda Cagar Budaya/situs sejarah di Cineam. Padahal pengetahuan ini sangat penting dan diperlukannya peran serta masyarakat untuk menjaganya.

Pernyataan tersebut juga diakui oleh masyarakat sekitar dari hasil Wawancara dengan masyarakat yaitu dengan fajar Setya Wicaksana, Mahmudi, dan Abdul Fatah yang berkesimpulan dari pernyataannya adalah (Wawancara, 20/08/2018): "Masyarakat disini belum menyadari bahwa Situs sejarah sangat penting keberadaannya, dan sangatlah dibutuhkan peran dari masyarakat untuk bersama-sama menjaga dan melestarikannya, tetapi kondisi masyarakat sekitar saya akui memang kurang peduli”.

Data tersebut menunjukkan, ternyata peran masyarakat di dalam pelestarian Situs sejarah Cineam sangatlah diperlukan, tentu saja juga akan dibantu oleh LSM yang terkait dalam hal ini, yang dalam hal ini masih aktif adal LSM Masyarakat Sejarawan Indonesia (MSI) Jawa Barat, maka masyarakat harus lebih memperhatikan Situs sejarah di Cineam.

Merujuk pada Undang - Undang Republik Indonesia Nomor 11 Tahun 2010 tentang Cagar Budaya pasal Pasal 55 yang berbunyi "Setiap orang dilarang dengan sengaja mencegah, menghalang-halangi, atau menggagalkan upaya Pelestarian Cagar Budaya”, dan di perkuat lagi 
pasal Pasal 57 "Setiap orang berhak melakukan Penyelamatan Cagar Budaya yang dimiliki atau yang dikuasainya dalam keadaan darurat atau yang memaksa untuk dilakukan tindakan penyelamatan”. Pasal 58 ayat (1) juga menjelaskan "Penyelamatan Cagar Budaya dilakukan untuk : a. mencegah kerusakan karena faktor manusia dan/atau alam yang mengakibatkan berubahnya keaslian dan nilai-nilai yang menyertainya; dan b. mencegah pemindahan dan beralihnya pemilikan dan/atau penguasaan Cagar Budaya yang bertentangan dengan ketentuan peraturan perundang-undangan".

Merujuk pada teori Soekmono (2012) Perubahan kebudayaan diakibatkan dua macam sebab, ialah: sebab yang berasal dari dalam, yaitu dari masyarakat pendukungnya sendiri, dan sebab yang berasal dari luar, yaitu dari luar lingkungan masyarakat.

Berdasarkan teori tersebut masyarakat sangatlah berperan dalam kebudayaan, yang dimaksud kebudayaan tersebut adalah Cagar Budaya/situs sejarah yang menjadi bagian dari masyarakat, jika masyrakat disini sangat peduli dengan Cagar Budaya/situs sejarah Cineam maka sangat mungkin untuk mencegah kerusakan yang berkelanjutan saat ini, dan jika masyarakat sangat peduli dengan situs sejarah tersebut maka pengaruh negatif dari luar lingkungan juga akan tidak masuk karena kepedulian masyarakat dengan Cagar Budaya sangat peduli.

Kebudayaan mengandung keseluruhan pengertian nilai sosial, norma sosial, ilmu pengetahuan serta keseluruhan struktur-struktur sosial, religious, dan lain-lain, tambahan lagi segala pernayataan intelektual dan artistik yang menjadi ciri khas suatu msyarakat. Kebudayaan juga menjadi suatu sistem konsep yang diwariskan yang terungkap dalam bentuk-bentuk simbolik yang dengannya manusia berkomunikasi, melestarikan, dan memperkembangkan pengetahuan mereka tentang kehidupan dan sikap-sikap terhadap kehidupan. Oleh karenanya kebudayaan merupakan pola tingkahlaku yang dipelajari dan disampaikan dari suatu generasi ke generasi berikutnya. Paling tidak ada tiga proses belajar kebudayaan yang penting, yaitu dalam kaitannya dengan manusia sebagai makhluk hidup dan sebagai suatu sistem sosial (Antonius, 2013:893; Koentjaraningrat, 2002:74; Soekmono, 2012:16).

Perhatian Pemerintah Kabupaten Tasikmalaya sangatlah dibutuhkan dan seharusnya Dinas Kebudayaan, Pariwisata, Pemuda, dan Olahraga harus mempunyai tim ahli dalam melakukan pelestarian di stus sejarah tersebut. Pelestarian benda cagar budaya/situs sejarah merupakan inspirasi bagi kelanjutan perjuangan kita dan menjauhkan terjadinya keterasingan sejarah yang dapat mengakibatkan kemiskinan budaya. Maka perlu ditumbuh kembangkan pernahaman tentang pelestarian benda cagar budaya, sehingga selalu diperhatikan keserasian, keseimbangan, dan kesinambungan antara aspek fisik dan aspek sosial budaya. Kedua aspek itu tidak dapat dipisahkan untuk mendukung upaya pelestarian benda cagar budaya. Bantuan dan dukungan masyarakat sangat diperlukan, karenapada hakekatnya pelestarian benda cagar budaya tersebut menjadi tanggung jawab kita. Untuk itulah sebagai bangsa yang besar dan 
berbudaya marilah kita lestarikan warisan kebudayaan masa lalu untuk kebesaran bangsa tercinta.

\section{Kearifan Lokal}

Kearifan lokal adalah dasar untuk pengambilan kebijakkan pada level lokal dibidang kesehatan, pertanian, pendidikan, pengelolaan sumber daya alam dan kegiatanmasyarakat pedesaan. Dalam kearifan lokal, terkandung pula kearifan budaya lokal.Kearifan budaya lokal sendiri adalah pengetahuan lokal yang sudah sedemikianmenyatu dengan sistem kepercayaan, norma, dan budaya serta diekspresikan dalamtradisi dan mitos yang dianut dalam jangka waktu yang lama, ciri-ciri kearifal lokal yaitu :

1. Mampu bertahan terhadap budaya luar

2. Memiliki kemampuan mengakomodasi unsur-unsur budaya luar

3. Mempunyai kemampuan mengintegrasikan unsur budaya luar ke dalam budaya asli

4. Mempunyai kemampuan mengendalikan

5. Mampu memberi arah pada perkembangan budaya

Kearifan lokal berfungsi untuk konservasi dan pelestarian sumberdaya alam, yaitu:

1. Kearifan lokal berfungsi untuk mengembangkan sumber daya manusia

2. Berfungsi sebagai pengembangan kebudayaan dan ilmu pengetahuan

3. Berfungsi sebagai petuah, petuah, kepercayaan, sastra dan pantangan

Selain itu, kearifan lokal terdiri dari enam dimensi yaitu :

1. Pengetahuan Lokal.

Setiap masyarakat dimanapun berada baik di pedesaan maupun pedalaman selalu memiliki pengetahuan lokal yang terkait dengan lingkungan hidupnya. Pengetahuan lokal terkait dengan perubahan dan siklus iklim kemarau dan penghujan, jenis-jenis fauna dan flora, dan kondisi geografi, demografi, dan sosiografi. Hal ini terjadi karena masyarakat mendiami suatu daerah itu cukup lama dan telah mengalami perubahan sosial yang bervariasi menyebabkan mereka mampu beradaptasi dengan lingkungannnya. Kemampuan adaptasi ini menjadi bagian dari pengetahuan lokal mereka dalam menaklukkan alam.

\section{Nilai Lokal}

Untuk mengatur kehidupan bersama antara warga masyarakat, maka setiap masyarakat memiliki aturan atau nilai-nilai lokal yang ditaati dan disepakati bersama oleh seluruh anggotannya. Nilai-nilai ini biasanya mengatur hubungan antara manusia dengan manusia, manusia dengan alam dan manusia dengan Tuhannnya. Nilai-nilai ini memiliki dimensi waktu, nilai masa lalu, masa kini dan masa datang, dan nilai ini akan mengalami perubahan sesuai dengan kemajuan masyarakatnya. 
3. Keterampilan Lokal

Kemampuan bertahan hidup (survival) dari setiap masyarakat dapat dipenuhi apabila masyarakat itu memiliki keterampilan lokal. Keterampilan lokal dari yang paling sederhana seperti berburu, meramu, bercocok tanam sampai membuat industri rumah tangga. Keterampilan lokal ini biasanya hanya cukup dan mampu memenuhi kebutuhan keluargannya masing-masing atau disebut dengan ekonomi subsisten. Keterampilan lokal ini juga bersifat keterampilan hidup (life skill), sehingga keterampilan ini sangat tergantung kepada kondisi geografi tempat dimana masyarakat itu bertempat tinggal.

4. Sumber daya Lokal

Sumber daya lokal ini pada umumnya adalah sumber daya alam yaitu sumber daya yang tak terbarui dan yang dapat diperbarui. Masyarakat akan menggunakan sumber daya lokal sesuai dengan kebutuhannya dan tidak akan mengekpoitasi secara besar-besar atau dikomersilkan. Sumber daya lokal ini sudah dibagi peruntukannnya seperti hutan, kebun, sumber air, lahan pertanian, dan permukiman, Kepemilikan sumber daya lokal ini biasanya bersifat kolektif atau communitarian.

\section{Mekanisme Pengambilan Keputusan Lokal}

Menurut ahli adat dan budaya sebenarnya setiap masyarakat itu memiliki pemerintahan lokal sendiri atau disebut pemerintahan kesukuan. Suku merupakan kesatuan hukum yang memerintah warganya untuk bertindak sebagai warga masyarakat. Masing-masing masyarakat mempunyai mekanisme pengambilan keputusan yang berbeda -beda. Ada masyarakat yang melakukan secara demokratis atau "duduk sama rendah berdiri sama tinggi". Ada juga masyarakat yang melakukan secara bertingkat atau berjenjang naik dan bertangga turun. Pendapat lain menyatakan bahwa bentuk kearifan lokal dapat dikategorikan ke dalam dua aspek, yaitu kearifan lokal yang berwujud nyata (tangible) dan yang tidak berwujud (intangible). Kearifal lokal dapat dipahami sebagai gagasan-gagasan msyarakat setempat yang bersifat bijaksana, penuh kearifan, nilai baik, yang tertanam, dan diikuti oleh anggota masyarakatnya (Sartini, 2004:111). Bentuk kearifam lokal dalam masyarakat antara lain nilai, norma, etika, kepercayaan, adat-istiadat, hokum adat, dan aturan khusus. Pada masyarakat yang hidup di lingkungan situs kearifan lokal diwujudkan dalam bentuk mitos, legenda, adat, kepercayaan, tradisi, dan organisasi-organisasi sosial

\section{Pelestarian Situs Berbasis Kearifan Lokal}

Konsep pelatihan pelestarian situs yang diberikan berdasarkan pada kearifan lokal yang dimiliki oleh Masyarakat Nagaratengah Kecamatan Cineam yaitu berdasarkan pada kepercayaan, tradisi, adat, organisasi-organisasi sosial, dan sistem pengelolaan. Pelatihan yang diberikan berupa penyuluhan kepada masyarakat bagaimana cara melalakukan pelestarian situs 
dan pengelolaan lingkungan di area situs dengan selalu menjaga kebersihan situs. Beberapa hal yang dapat membangun sinergi dan keterlibatan masyarakat dalam pelestarian situs, antara lain :

1. Merumuskan komitmen bersama dan menyatukan visi, misi dalam pelestarian situs yang berbasis pada kearifan lokal berupa organisasi-organisasi sosial yang terdapat pada masyarakat Nagaratengah

2. Membentuk kemandirian dalam upaya menjalin keharmonisan antar masyarakat

3. Bergerak dalam keragaman untuk melalui proses yang penuh tantangan

4. Mengaktifkan organisasi-organisasi yang ada di masyarakat dan media sosial dalam konsep pelestarian situs

Pelestarian dan pengelolaan situs harus terjalin hubungan yang harmonis antara sumber daya manusia, untuk menghindari konflik kepentingan antar warga atau antar kelompok masyarakat. Situs yang terdapat di Nagaratengah termasuk sebagai peninggalan para karuhun (leluhur), situs ini dianggap mistis yang dijaga oleh masyarakat secara sukarela, tetapi masyarakat belum memahami cara pelestarian situs saat ini pelestraian hanya dilakukan pada sebatas memelihara kebersihan dilingkungan situs atau makam.

Keberadaan makam tersebut, merupakan makam Panji Jayanegara yang merupakan penyebar agama Islam di daerah Cineam khususnya Nagaratengah, berdasarkan sumber yang didapat Panji Jayanegara juga berperan dalam proses penyebaran Islam di wilayah priangan bagian utara. Sehingga makam tersebut oleh masyarakat setempat disakralkan, bahkan sudah ada pengunjung yang berziarah. Untuk menjaga keberaadaan situs tersebut agar tetap utuh, maka dilakukan pelatihan pada msyarakat bagaimana memelihara situs seperti memahami batuan yang ada di atas makam agar bisa dibedakan dengan batu yang ada disekitarnya, menjaga benda-benda yang ada disekita situs, melakukan pelatihan bagaimana menjadi narasumber dalam menjelaskan keberadaan situs tersebut, dan menjadikan situs sebagai tempat wisata religi dan membangun kesadaran masyarakat untuk menjaga keberadaan situs tersebut.

\section{KESIMPULAN DAN SARAN}

Beberapa hal yang dapat membangun sinergi dan keterlibatan masyarakat dalam pelestarian situs, antara lain merumuskan komitmen bersama dan menyatukan visi, misi dalam pelestarian situs yang berbasis pada kearifan lokal berupa organisasi-organisasi sosial yang terdapat pada masyarakat Nagaratengah. Selain itu harus dibentuk kemandirian dalam upaya menjalin keharmonisan antar masyarakat. Terakhir adalah mengaktifkan organisasi-organisasi yang ada di masyarakat dan media sosial dalam konsep pelestarian situs. Masyarakat Cineam masih belum memahami dalam usaha melestarikan situs sejarah di wilayahnya dan juga tidak tahu pelanggaran yang diterima jika merusak situs sejarah tersebut. Dengan situasi yang seperti 
ini diperlukan perda agar perlindungan hukum terjamin, pelestariannya jelas, dan anggarannya juga jelas.

\section{DAFTAR PUSTAKA}

Antonius, Mikahel. 2013. "Studi tentang Pelestarian Cagar Budaya Masyarakat Dayak Bulusu di Desa Terindak Kecamatan Sekatak Kabupaten Bulungan”. eJournal Ilmu Pemerintahan Fisip Universitas Mulawarman. Volume 1 (3) 899-900.

Koentjaraningrat. 2002. Kebudayaan Mentalitas dan Pembangunan. Jakarta: Gramedia.

Sartini. 2004. "Menggali Kearifan Lokal Nusantara Sebuah Kajian Filsafati". Jurnal Filsafat. Volume 37 (2): 111-120.

Soekmono. 2012. Pengantar Sejarah Kebudayaan Indonesia I. Yogyakarta : Anggota IKAPI. 